\title{
Characteristics of carcass and non-carcass components of lambs fed wet brewery waste as a roughage feed
}

\section{Características da carcaça e dos componentes não- carcaça de cordeiros alimentados com resíduo úmido de cervejaria como alimento volumoso}

\author{
Sérgio Carvalho ${ }^{1}$; Verônica Manzonii; Claudia Flores Minuzi ${ }^{3 *}$; William Soares \\ Teixeira2; Viviana Reboledo da Costa4; Larissa Lopes Barbosa3; Pablo Marques

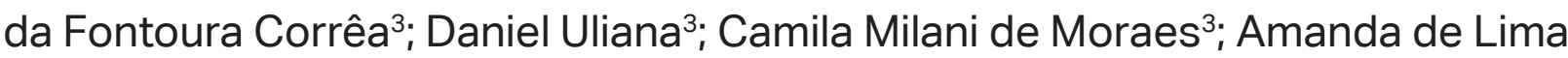 \\ Ozorio $^{3}$; Mariana de Oliveira ${ }^{3}$
}

\section{Highlights}

Hot and cold carcass yields decrease with dietary inclusion of WBW.

Gastrointestinal content and fasting losses increase with dietary inclusion of WBW.

$31 \%$ WBW inclusion in the feedlot diet provides better results of carcass traits.

\begin{abstract}
The objective of the present study was to evaluate the effect of including wet brewery waste (WBW) as the exclusive dietary roughage source on the characteristics of carcass and non-carcass components of feedlot-finished lambs. Thirty-two non-castrated male lambs weaned at 50 days of age, resulting from the cross between the Texel and lle de France breeds, were used. The diet was constituted by roughage (WBW) and a concentrate composed of crushed maize, soybean meal, limestone and common salt. Treatments consisted of four levels of WBW as the roughage source in the diet (\% dry matter), namely, 31, 44, 57 and $70 \%$. Lambs were slaughtered upon reaching $34 \mathrm{~kg}$ live weight. The treatments resulted in a linear decrease in hot and cold carcass weights and yields, carcass compactness index, conformation, degree of fatness and rib-eye area. Among the primal cuts, the absolute weights of pallet, ribs and legs decreased as the WBW level was increased. As to the non-carcass components, only the total gastrointestinal content increased

1 Prof., Postgraduate Course in Zootechnics, Federal University of Santa Maria, UFSM, Santa Maria, RS, Brazil. E-mail: scarvalhoufsm@hotmail.com

2 Students of the Doctoral Course of the Postgraduate Program in Animal Science, UFSM, Santa Maria, RS, Brazil. E-mail: vemanzoni@hotmail.com; williamteixeira.wsr@gmail.com

3 Students of the Undergraduate Course in Science, UFSM, Santa Maria, RS, Brazil. E-mail: cfloresminuzzi@gmail.com; larissalopesbarbosa@hotmail.com; p4blo.fontoura.m@gmail.com; danielvedovatouliana@gmail.com; milanicamila@ hotmail.com; amandalimaozorio@gmail.com; marianadallaf@gmail.com

${ }^{4}$ Student of the Master's Course in the Postgraduate Program in Animal Science, UFSM, Santa Maria, RS, Brazil. E-mail: totydca05@hotmail.com

* Author for correspondence
\end{abstract}

Received: Aug. 24, 2020 - Approved: Jan. 18, 2021 
linearly with WBW. The increasing levels of WBW led to greater fasting losses and reduced carcass weights and yields. There was also a reduction in the degree of fatness, carcass compactness, carcass conformation index and rib-eye area Wet brewery waste at the concentration of $31 \%$ as the roughage source in the diet of finishing lambs in the feedlot provides better carcass traits.

Key words: By-product. Components of live weight. Qualitative traits. Sheep. Slaughter.

\section{Resumo}

O objetivo do presente trabalho foi avaliar o efeito da inclusão de resíduo úmido de cervejaria (RUC) como fonte exclusiva de volumoso sobre as características da carcaça e dos componentes não-carcaça de cordeiros terminados em confinamento. Foram utilizados 32 cordeiros, machos, não castrados, desmamados com 50 dias de idade e provenientes de cruzamento entre as raças Texel e lle de France. A dieta foi composta por volumoso, sendo este o RUC, e por concentrado composto de milho desintegrado, farelo de soja, calcário calcítico e sal comum. Os tratamentos foram constituídos por quatro teores de RUC como volumoso da dieta (\% da MS), sendo: 31, 44, 57 e 70\%. Os cordeiros foram abatidos quando atingiram $34 \mathrm{~kg}$ de peso vivo. Os tratamentos exerceram influência negativa de maneira linear decrescente sobre os pesos e rendimentos de carcaça quente e fria, índice de compacidade de carcaça, conformação, estado de engorduramento e área de olho de lombo. Entre os cortes comerciais, a medida que aumentou o nível de RUC diminuíram os pesos absolutos de paleta, costilhar e perna. Quando avaliados os componentes não-carcaça, verificou-se que apenas o conteúdo gastrointestinal total aumentou linearmente com a elevação do teor de RUC. O aumento da inclusão de RUC levou a maiores perdas por jejum e reduziu os pesos e rendimentos de carcaça. Também ocorreu redução no estado de engorduramento, no índice de compacidade e conformação da carcaça, bem como da área de olho de lombo. O teor de 31\% de RUC como alimento volumoso na terminação de cordeiros em confinamento proporcionou melhores características na carcaça dos animais.

Palavras-chave: Abate. Características qualitativas. Componentes do peso vivo. Ovinos. Subproduto.

\section{Introduction}

Sheep farming for meat production is an activity that has been gradually established in Brazil. According to data from Instituto Brasileiro de Geográfia e Estatística [IBGE] (2018), the national sheep herd rose from 15.5 million in 2005 to 17.97 million in 2017. Despite this increase, the current sheep meat production cannot meet the demand of the consumer market (Carvalho et al., 2017), which indicates the great growth potential of the sector.
This consumer market demand stimulates an intensification of production, which can beachieved with the use of the feedlot as a finishing system. In addition to allowing for a shorter production cycle, feedlot-finishing contributes to the production of quality meat. However, one of the obstacles to the use of feedlots is the increased production costs due to the feed, the most significant component of the total cost in this system (Carvalho et al., 2017). Therefore, feed alternatives must be sought that render their adoption viable while improving the animal carcass traits. 
Wet brewery waste (WBW) is a byproduct from the brewing industry with high nutritional quality. In addition to having great potential for animal production, WBW is available in large volumes throughout the year and can be obtained at a low cost at brewing industries (Carvalho et al., 2017). Moreover, thanks to its good protein content and elevated neutral detergent fiber levels, WBW can be used as an alternative roughage source in ruminant diets (Silva et al., 2010).

The feed provided to animals can influence several aspects related to traits of their carcass (Gois et al., 2019; Hashimoto et al., 2012) as well as of non-carcass components, which can represent 40 to $60 \%$ of live weight (Gois et al., 2019). Despite having no defined commercial value in terms of carcass yield, these components are considered in the sale of live animals and are paid for after slaughter.

In this scenario, the hypothesis tested in the present study is that WBW can be used as a roughage feed in the diet of feedlot lambs without negatively affecting the characteristics of their carcass and non-carcass components. Therefore, this study examined the effect of WBW inclusion in the diet, as a roughage source, on the characteristics of carcass and non-carcass components of feedlot-finished lambs.

\section{Material and Methods}

The study was conducted at the Sheep Farming Laboratory of the Department of Animal Science at the Federal University of Santa Maria, located in Santa Maria - RS, Brazil, from March 2016 to June 2018. This experiment followed the standards of and was approved by the Ethics Committee on Animal
Experimentation of the institution (approval no. 9138100516). In the laboratory phase, it was developed at the Integrated Unit for the Development of Laboratory Analyses (Nidal) at the Federal University of Santa Maria, state of Rio Grande do Sul.

Thirty-two non-castrated male lambs resulting from a cross between the Texel and lle de France breeds, weaned at 50 days of age, were used. The animals had an average initial live weight of $21.62 \pm 3.09 \mathrm{~kg}$ and were properly dewormed with Ripercol ${ }^{\circledR}$ (levamisole hydrochloride at a dose of $1 \mathrm{~mL}$ for every 10 $\mathrm{kg}$ of body weight) and vaccinated against clostridial infections with the Poly-Hepta vaccine $(2 \mathrm{~mL}$ at the beginning of the feedlot period and $2 \mathrm{~mL}$ of booster 21 days after the first dose). After weaning, the animals were confined in individual covered stalls with suspended slatted floors approximately $1.0 \mathrm{~m}$ above the ground. Each stall measured $2 \mathrm{~m}^{2}$ and was equipped with individual feeders and drinkers where feed and water were provided.

Lambs were distributed into four treatment groups in a completely randomized experimental design with eight replicates (lambs). The treatments consisted of different levels of roughage, with WBW constituting the exclusive roughage source of the diet, at levels of $31,44,57$ and $70 \%$, on a dry matter (DM) basis.

The diets were formulated to be isoproteic, in accordance with the National Research Council [NRC] (2007), and calculated to meet the requirements for a daily weight gain of $0.200 \mathrm{~kg}$ in late-maturing lambs. The diets were composed of WBW and a concentrate made up of crushed maize (Zea mays L.), soybean meal (Glycine max L.), limestone and common salt (Table 1 ). The Ca:P ratio was 
2:1. The roughage:concentrate ratio varied according to the treatment, on a DM basis, to achieve the desired WBW content of each experimental diet (Table 2). Wet brewery waste was obtained from a beer agroindustry in Santa Maria - RS, Brazil, and was preserved in the form of silage in a trench silo, with no compaction required. To seal the silo, a specific canvas for silage-making (double-face, 8-m wide, 200- $\mu$ thick) was used. The WBW remained ensiled for four months before being supplied to the lambs.

\section{Table 1}

Dry matter content (\% as-fed) and chemical composition (\% of dry matter) of the ingredients used in the formulation of the experimental diets

\begin{tabular}{|cccccc|}
\hline Item & $\begin{array}{c}\text { Brewery } \\
\text { waste }\end{array}$ & $\begin{array}{c}\text { Cracked } \\
\text { corn }\end{array}$ & $\begin{array}{c}\text { Soybean } \\
\text { meal }\end{array}$ & $\begin{array}{c}\text { Calcitic } \\
\text { limestone }\end{array}$ & $\begin{array}{c}\text { Common } \\
\text { salt }\end{array}$ \\
\hline DM & 24.20 & 87.82 & 87.55 & 100.00 & 100.00 \\
OM & 93.70 & 98.54 & 92.59 & - & - \\
\hline CP & 21.18 & 9.23 & 53.18 & - & - \\
EE & 8.91 & 0.90 & 3.36 & - & - \\
\hline NDF & 63.71 & 10.37 & 12.94 & - & - \\
\hline ADF & 22.40 & 2.14 & 4.83 & - & - \\
\hline TC & 63.61 & 88.41 & 36.05 & - & - \\
\hline TDN & 66.12 & 87.24 & 81.50 & - & - \\
\hline ADL & 8.47 & 0.82 & 2.19 & - & - \\
\hline Ash & 6.30 & 1.46 & 7.41 & 100.00 & 100.00 \\
Ca & 0.23 & 0.03 & 0.34 & 34.00 & - \\
P & 0.70 & 0.25 & 0.58 & 0.02 & - \\
\hline
\end{tabular}

'DM: dry matter; OM: organic matter; CP: crude protein; EE: ether extract; NDF: neutral detergent fiber; ADF: acid detergent fiber; TC: total carbohydrates; TDN: total digestible nutrients; ADL: lignin; Ca: calcium; P: phosphorus.

${ }^{2}$ Tabulated value (Valadares; Paulino \& Magalhães, 2006). 
Table 2

Proportion of ingredients (\% DM) and chemical composition of the experimental diets

\begin{tabular}{|ccccc|}
\hline & \multicolumn{4}{c}{ Wet brewery waste level (\%) } \\
\cline { 2 - 4 } Component $^{1}$ & 31 & 44 & 57 & 70 \\
\hline Brewery waste & Proportion of ingredients (\% DM) & \\
\hline Cracked corn & 31.00 & 44.00 & 57.00 & 70.00 \\
\hline Soybean meal & 51.84 & 42.14 & 32.37 & 22.61 \\
\hline Calcitic limestone & 14.03 & 10.53 & 7.05 & 3.57 \\
\hline Common salt & 2.13 & 2.33 & 2.58 & 2.82 \\
\hline & 1.00 & 1.00 & 1.00 & 1.00 \\
\hline DM & Chemical composition (\% DM) & & 43.74 \\
\hline OM & 68.44 & 60.20 & 51.97 & 91.18 \\
\hline CP & 93.12 & 92.50 & 91.83 & 18.81 \\
\hline EE & 18.81 & 18.81 & 18.81 & 6.56 \\
\hline NDF & 3.70 & 4.65 & 5.61 & 47.40 \\
\hline ADF & 26.94 & 33.76 & 40.58 & 16.34 \\
\hline TC & 8.73 & 11.27 & 13.80 & 65.81 \\
\hline ADL & 70.61 & 69.04 & 67.42 & 6.19 \\
\hline TDN & 3.36 & 4.30 & 5.25 & 68.92 \\
\hline Ash & 77.16 & 74.44 & 71.68 & 8.82 \\
Ca & 6.88 & 7.50 & 8.17 & 1.14 \\
\hline P & 0.86 & 0.94 & 1.04 & 0.57 \\
\hline & 0.43 & 0.47 & 0.52 & \\
\hline
\end{tabular}

'DM: dry matter; OM: organic matter; CP: crude protein; EE: ether extract; NDF: neutral detergent fiber; ADF: acid detergent fiber; TC: total carbohydrates; TDN: total digestible nutrients; ADL: lignin; Ca: calcium; P: phosphorus.

Before the experimental period began, the animals were allowed ten days of acclimation to the facilities, feeding and management conditions. The diets were supplied ad libitum twice daily: in the morning (08h00) and in the afternoon (17h00), to ensure maximum voluntary intake. The amount provided was adjusted according to the refusals of the previous day, allowing $10 \%$ orts per day.

Upon reaching 34 to $35 \mathrm{~kg}$ of live weight, which corresponds to approximately $60 \%$ of the adult live weight, the animals were weighed (final live weight, FLW). Subsequently, they were deprived of feed and water for $14 \mathrm{~h}$. After this time, the lambs were weighed again (slaughter weight, SW). Fasting losses (FL) were determined in percentage values (\%), as follows: $F L=100-[(S W \times 100) / F L W]$.

Then, the animals were stunned with a captive bolt pistol and slaughtered. After the skinning and evisceration procedures, their carcass was weighed to determine hot carcass weight (HCW). The ratio between HCW and $\mathrm{SW}$ resulted in the hot carcass yield $(\mathrm{HCY}$ $=(\mathrm{HCW} / \mathrm{SW}) \times 100)$. Next, the carcasses were 
refrigerated in a cold room at $2^{\circ} \mathrm{C}$ for $24 \mathrm{~h}$. After the chilling period, the carcasses were weighed again to obtain cold carcass weight (CCW), cold carcass yield $(C C Y=(C C W / S W) \times 100)$ and chilling loss $(\mathrm{CL}=100-[(\mathrm{CCW} / \mathrm{HCW}) \times 100])$. The carcass compactness index $(\mathrm{CCl}=\mathrm{CCW} /$ internal carcass length) was also calculated, following the methodology of Osório, Osório, Jardim and Pimentel (1998).

On the cold carcass, conformation was evaluated on a scale from 1 (poor) to 5 (excellent) and the degree of fatness was also estimated also using a scale from 1 (very thin) to 5 (very fat), according to methodologies described by Osório et al. (1998). Then, the ribeye area (REA) was obtained by exposing the Longissimus dorsi muscle after a cross-section between the 12th and 13th ribs, and tracing its outline on parchment paper. To determine and record the area, Image $J^{\circledR}$ software version 1.51 was used. In the same region, backfat thickness (BFT) was measured using a digital caliper and texture (1.0 = very coarse and 5.0 $=$ very thin), marbling (1.0 = absent and $5.0=$ excessive) and color (1.0 = light pink and $5.0=$ dark red) were evaluated subjectively (Osório et al., 1998). Subsequently, the carcass was sectioned in half, in the caudocranial direction, and the right half was weighed and divided into the following primal cuts (Osório et al., 1998): neck, shoulder, rib and leg. Once separated, the cuts were weighed and their percentage calculated relative to the weight of the right half carcass.

For the evaluation of non-carcass components, all blood was collected and skin, feet, head, penis (termed "external organs"); heart, kidneys, liver, lungs + trachea, spleen, diaphragm, pancreas, bladder ("internal organs"); and inguinal, renal, ruminal and heart fats ("internal fats") were all removed weighed separately. Rumen, reticulum, omasum, abomasum, small intestine and large intestine ("gastrointestinal organs") were also weighed individually, with gastrointestinal content (GIC). Immediately afterwards, the different compartments were emptied, thoroughly washed and weighed again after draining. The weight of the content of each gastrointestinal tract organ (full or empty) was determined by difference. Total GIC was determined as the sum of the contents of each organ. Then, the percentage of the different internal organs was calculated individually relative to the SW of the animals.

After analyzing the data set, influential observations (outliers, i.e. values that dispersed from the distribution in the normality test) were excluded. Subsequently, the data were subjected to the Shapiro-Wilk normality test $(P<0.05)$, followed by analysis of variance and linear and quadratic regression in relation to the WBW inclusion levels. The equations were selected based on the coefficients of determination and the significance of the regression coefficients, adopting the 5\% probability level. Statistical analyses were carried out using Statistical Analysis System Institute [SAS INSTITUTE INC] (2016) software version 3.6.

\section{Results and Discussion}

The WBW levels did not influence FLW or SW (Table 3). This result was expected, since a FLW in the range of 34 to $35 \mathrm{~kg}$ was predetermined as a reference for slaughter, in view of the desired physiological and tissue maturity. It is important to mention that the number of days of in feedlot required for the animals to reach FLW did not differ between the treatments, averaging $38 \pm 13$ days (Table 3 ). 
An important fact to be highlighted is that the increasing dietary WBW content was accompanied by an increase in the fiber content and a reduction in the energy content of the diets (Table 2). In this respect, FLW increased linearly with WBW, which can be explained by the fact that as the amount of roughage was increased, the proportion of fiber and lignin in the diets also increased (Table 2) and, consequently, so did the amount of gastrointestinal content (Table 4).
Although SW did not differ between the animals, HCW and CCW decreased linearly with the inclusion of WBW (Table 3). Because the diets were isoproteic, this result is attributed to their reduced energy density as a consequence of the increasing fiber content provided by the inclusion of WBW. This is not interesting from a productive point of view, since a reduction in carcass weight will translate into a lower amount of edible material to the final consumer after slaughter, compromising the sheep meat production chain as a whole.

\section{Table 3}

Days to reach slaughter weight and carcass traits of lambs fed increasing levels of wet brewery waste (WBW) in the feedlot

\begin{tabular}{|c|c|c|c|c|c|c|c|}
\hline \multirow{2}{*}{ Variable $^{1}$} & \multicolumn{4}{|c|}{ Wet brewery waste level (\%) } & \multirow{2}{*}{ Regression equation } & \multirow{2}{*}{$\mathrm{R}^{2}$} & \multirow{2}{*}{$\operatorname{Pr}>\mathrm{F}$} \\
\hline & 31 & 44 & 57 & 70 & & & \\
\hline DAYS (n) & 39 & 31 & 37 & 46 & $\bar{y}=38$ & - & 0.1862 \\
\hline FLW (kg) & 34.87 & 34.27 & 34.34 & 34.31 & $\bar{y}=34.45$ & - & 0.2619 \\
\hline SW (kg) & 33.45 & 32.57 & 32.79 & 32.42 & $\bar{y}=32.81$ & - & 0.0644 \\
\hline FL (\%) & 4.08 & 4.94 & 4.52 & 5.52 & $\bar{y}=3.25493+0.02989 W B W$ & 0.13 & 0.0396 \\
\hline HCW (kg) & 17.07 & 15.88 & 15.46 & 15.22 & $\bar{y}=18.22653-0.04591 W B W$ & 0.48 & $<0.0001$ \\
\hline CCW (kg) & 16.40 & 15.35 & 14.89 & 14.62 & $\bar{y}=17.56823-0.04468 W B W$ & 0.45 & $<0.0001$ \\
\hline HCY (\%) & 51.03 & 48.78 & 47.20 & 46.94 & $\bar{y}=53.86062-0.10642 W B W$ & 0.39 & 0.0001 \\
\hline $\operatorname{CCY}(\%)$ & 49.01 & 47.14 & 45.44 & 45.09 & $\bar{y}=51.89769-0.10359 W B W$ & 0.38 & 0.0002 \\
\hline CL (\%) & 3.96 & 3.36 & 3.73 & 3.97 & $\bar{y}=3.76$ & - & 0.7805 \\
\hline $\mathrm{CCl}\left(\mathrm{kg} \mathrm{cm}^{-1}\right)$ & 0.29 & 0.28 & 0.26 & 0.26 & $\bar{y}=0.31560-0.00087 W B W$ & 0.43 & $<0.0001$ \\
\hline CONF (1-5) & 3.63 & 3.31 & 3.13 & 2.81 & $\bar{y}=4.23846-0.02019 W B W$ & 0.33 & 0.0007 \\
\hline DF (1-5) & 3.44 & 3.38 & 2.63 & 2.81 & $\bar{y}=4.08221-0.02019 W B W$ & 0.22 & 0.0064 \\
\hline $\mathrm{BFT}(\mathrm{mm})$ & 2.61 & 2.18 & 1.68 & 1.99 & $\bar{y}=2.11$ & - & 0.1151 \\
\hline TXT (1-5) & 3.63 & 3.44 & 3.31 & 3.25 & $\bar{y}=3.41$ & - & 0.0524 \\
\hline $\operatorname{MAR}(1-5)$ & 2.06 & 2.94 & 2.25 & 2.31 & $\bar{y}=2.39$ & - & 0.9583 \\
\hline $\operatorname{COR}(1-5)$ & 3.13 & 3.44 & 3.13 & 3.19 & $\bar{y}=3.22$ & - & 0.8827 \\
\hline $\operatorname{REA}\left(\mathrm{cm}^{2}\right)$ & 16.79 & 15.30 & 14.90 & 13.21 & $\bar{y}=19.37779-0.08567 W B W$ & 0.32 & 0.0008 \\
\hline
\end{tabular}

'DAYS: number of days to slaughter; FLW: final live weight; SW: slaughter weight; FL: fasting loss; HCW: hot carcass weight; CCW: cold carcass weight; CCY: cold carcass yield; HCY: hot carcass yield; CL: chilling loss; CCI: carcass compactness index; CONF: carcass conformation; DF: degree of fatness in the carcass; BFT: backfat thickness; TXT: meat texture; MAR: meat marbling; COR: subjective color; REA: rib-eye area. 
Hot and cold carcass yields (Table 3 ) decreased as a consequence of the greater gastrointestinal content resulting from the increasing proportions of WBW in the diet (Table 5). This finding is in agreement with Carvalho et al. (2017), who stated that carcass yields are greatly influenced by the fiber content of the diet. The result found in the present study is also in line with Brochier and Carvalho (2009), who investigated the effect of different proportions of WBW replacing concentrate feed on carcass traits of feedlot-finished lambs and observed a linear decrease in $\mathrm{HCY}$ and CCY as the WBW content was increased. The authors attributed the decrease in these yields to the increase in the neutral detergent fiber (NDF) content of the diets, which went from $29.4 \%$ in the diet without WBW to $54.6 \%$ at the replacement level of $100 \%$. The same response was observed in the present study, where the dietary NDF content also increased with WBW inclusion (Table 2).

Chilling loss, which indicates the percentage of weight lost during the chilling of the carcass, was not influenced by the treatments (Table 3), averaging $3.74 \%$. This value is considered acceptable, since CL should be between 3.0 and $4.0 \%$ (Lima et al., 2013). The statistical similarity found can also be associated with the data obtained for BFT, which maintained a similar behavior to $\mathrm{CL}$. It is important to emphasize that BFT is of great relevance in that it protects the carcass against moisture loss during chilling. Therefore, it influences CL.

\section{Table 4}

Non-carcass components of lambs fed increasing levels of wet brewery waste (WBW) in the feedlot

\begin{tabular}{|c|c|c|c|c|c|c|c|}
\hline \multirow{2}{*}{ Variable $^{1}$} & \multicolumn{4}{|c|}{ Wet brewery waste level (\%) } & \multirow{2}{*}{ Regression equation } & \multirow{2}{*}{$\mathrm{R}^{2}$} & \multirow{2}{*}{$\operatorname{Pr}>F$} \\
\hline & 31 & 44 & 57 & 70 & & & \\
\hline \multicolumn{8}{|c|}{ Weight (kg) } \\
\hline EO & 7.21 & 6.95 & 7.14 & 6.82 & $\bar{y}=7.03$ & - & 0.1409 \\
\hline 10 & 1.53 & 1.51 & 1.56 & 1.48 & $\bar{y}=1.52$ & - & 0.5030 \\
\hline $\mathrm{GIO}$ & 2.02 & 1.99 & 2.12 & 2.06 & $\bar{y}=2.04$ & - & 0.4257 \\
\hline TGIO & 4.24 & 4.83 & 5.36 & 5.68 & $\bar{y}=3.14434+0.03726 W B W$ & 0.34 & 0.0005 \\
\hline IF & 0.82 & 0.74 & 0.73 & 0.70 & $\bar{y}=0.75$ & - & 0.1249 \\
\hline \multicolumn{8}{|c|}{ Yield (\%) } \\
\hline 10 & 4.57 & 4.64 & 4.75 & 4.56 & $\bar{y}=4.63$ & - & 0.7874 \\
\hline $\mathrm{GIO}$ & 6.02 & 6.09 & 6.45 & 6.34 & $\bar{y}=6.22$ & - & 0.1005 \\
\hline TGIO & 12.68 & 14.80 & 16.29 & 17.52 & $\bar{y}=9.1146+0.12292 W B W$ & 0.41 & $<0.0001$ \\
\hline IF & 2.43 & 2.28 & 2.23 & 2.15 & $\bar{y}=2.27$ & - & 0.1932 \\
\hline
\end{tabular}

${ }^{1} \mathrm{EO}$ : external organs; IO: internal organs; GIO: gastrointestinal organs; TGIC: total gastrointestinal content; IF: internal fats.

Carcass compactness index, which indicates the deposition of muscle tissue per unit of carcass length, as well as conformation, which expresses the development of muscle mass, decreased linearly as the WBW content was increased (Table 3). This result is a consequence of lesser muscle development in the animals, as evidenced by the reduction 
in REA with the increasing WBW levels (Table 3). Rib-eye area is considered a representative measure of the quantity and distribution of muscle mass as well as the quality of the carcass (Hashimoto et al., 2012). This smaller amount of muscle per unit of carcass length can be associated with a reduction in the energy content of the diet resulting from the increasing WBW content, which also led to a reduction in the weight and fatness degree of the carcasses.

The WBW levels did not influence $\mathrm{BFT}$, texture, marbling, or color of the meat. Carvalho et al. (2017) evaluated the effect of replacing sorghum silage with WBW in the diet of feedlot lambs and also found no significant effect of the WBW levels on these traits. In this study, the color variable, which is the first trait observed by the consumer when purchasing (Osório, Osório, Fernandes, \& Vargas, 2014), averaged 3.2. The meat color ranged between light red and red, which is the color desired by the consumer (Osório, Osório, \& Sañudo, 2009). The absence of an effect of the WBW levels on color can be explained by the fact that different feedstuffs have little influence on this attribute, due to the intense transformations they undergo in the rumen (Osório et al., 2014).

The weights of shoulder, rib and leg decreased linearly with the dietary inclusion of WBW (Table 5), following the response shown by HCW and CCW, as discussed previously. Neck weight was similar between the treatments. These results disagree with those observed by Carvalho et al. (2017), who evaluated increasing levels of replacement $(0,33.5,66.5$ and $100 \%)$ of sorghum silage with WBW and obtained similar weights for all primal cuts. The authors attributed the results to the similar nutritional composition of the treatments, which did not occur in the present study, since there was a reduction in the energy value of the diets as the proportion of WBW was increased (Table 2). This means there was less muscle development in the animals, which is also confirmed by the reduction in carcass conformation.

\section{Table 5}

Weight and yield of commercial cuts of lamb carcass fed increasing levels of wet brewery waste (WBW) in the feedlot

\begin{tabular}{|c|c|c|c|c|c|c|c|}
\hline \multirow{2}{*}{ Variable $^{1}$} & \multicolumn{4}{|c|}{ Wet brewery waste level (\%) } & \multirow{2}{*}{ Regression equation } & \multirow{2}{*}{$\mathrm{R}^{2}$} & \multirow{2}{*}{$\operatorname{Pr}>\mathrm{F}$} \\
\hline & 31 & 44 & 57 & 70 & & & \\
\hline \multicolumn{8}{|c|}{ Weight (kg) } \\
\hline Neck & 0.51 & 0.54 & 0.52 & 0.41 & $\bar{y}=0.49$ & - & 0.1219 \\
\hline Shoulder & 1.56 & 1.43 & 1.43 & 1.37 & $\bar{y}=1.66389-0.00434 W B W$ & 0.24 & 0.0041 \\
\hline Rib & 3.45 & 3.16 & 2.98 & 3.04 & $\bar{y}=3.70888-0.01095 W B W$ & 0.28 & 0.0020 \\
\hline Leg & 2.69 & 2.55 & 2.52 & 2.49 & $\bar{y}=2.7976-0.00468 W B W$ & 0.26 & 0.0027 \\
\hline \multicolumn{8}{|c|}{ Yield (\%) } \\
\hline Neck & 6.14 & 7.05 & 6.97 & 5.62 & $\bar{y}=6.44$ & - & 0.4965 \\
\hline Shoulder & 19.00 & 18.60 & 19.18 & 18.74 & $\bar{y}=18.88$ & - & 0.9320 \\
\hline Rib & 42.05 & 41.11 & 40.05 & 41.52 & $\bar{y}=41.18$ & - & 0.4629 \\
\hline Leg & 32.81 & 33.23 & 33.81 & 34.12 & $\bar{y}=31.74745+0.03457 W B W$ & 0.21 & 0.0091 \\
\hline
\end{tabular}


Regarding the proportions of primal cuts, the proportion of leg increased linearly with the WBW levels (Table 4). This finding is in agreement with Pellegrin et al. (2013), who evaluated the proportions of lamb carcass cuts and reported that only the proportion of legs increased. The result obtained can be considered positive from the production standpoint, since the leg is one of the primal cuts most valued by the consumer. The proportions of shoulder, ribs and neck were not influenced by the increasing levels of WBW in the lamb diets (Table 4).

Non-carcass components (external organs, internal organs, gastrointestinal organs and internal fat) were not influenced by the dietary inclusion of WBW (Table 5). This result is in line with the descriptions of Moreno et al. (2011), who stated that organs linked to the digestion and metabolism of food, as well as organs of the respiratory tract, brain and heart, are not influenced by the composition of the diet because they are prioritized in the use of nutrients, maintaining their integrity regardless of the nutritional status of the animal. This similarity was also expected, since the animals had similar characteristics, e.g. a predefined SW and the same genotype, age and sex.

Total gastrointestinal content (expressed both in kilograms and \%SW) increased linearly with the proportion WBW (Table 5) and, consequently, of fiber, in the diet fed to the animals. This had a negative impact on HCY and CCY, as previously discussed. This result was mainly influenced by the rumen content (Table 6), which represents the largest proportion of the total GIC of animals at the time of slaughter.

\section{Table 6}

Components of the gastrointestinal tract, with and without content, expressed as a \% of live weight at slaughter, of lambs fed increasing levels of wet brewery waste (WBW) in the feedlot

\begin{tabular}{|c|c|c|c|c|c|c|c|}
\hline \multirow{2}{*}{ Variable $^{1}$} & \multicolumn{4}{|c|}{ Wet brewery waste level (\%) } & \multirow{2}{*}{ Regression equation } & \multirow{2}{*}{$\mathrm{R}^{2}$} & \multirow{2}{*}{$\operatorname{Pr}>\mathrm{F}$} \\
\hline & 31 & 44 & 57 & 70 & & & \\
\hline FRum & 9.15 & 10.75 & 12.61 & 13.79 & $\bar{y}=5.44582+0.12133 W B W$ & 0.47 & $<0.0001$ \\
\hline ERum & 1.62 & 1.70 & 1.87 & 1.77 & $\bar{y}=1.74$ & - & 0.2832 \\
\hline FRet & 0.33 & 0.50 & 0.43 & 0.40 & $\bar{y}=0.41$ & - & 0.5442 \\
\hline ERet & 0.26 & 0.23 & 0.25 & 0.27 & $\bar{y}=0.25$ & - & 0.6679 \\
\hline FOma & 0.35 & 0.34 & 0.37 & 0.45 & $\bar{y}=0.24535+0.00257 W B W$ & 0.16 & 0.0215 \\
\hline EOma & 0.20 & 0.19 & 0.20 & 0.24 & $\bar{y}=0.21$ & - & 0.0798 \\
\hline FAbo & 1.64 & 1.82 & 1.51 & 1.57 & $\bar{y}=1.63$ & - & 0.3122 \\
\hline EAbo & 0.48 & 0.49 & 0.48 & 0.48 & $\bar{y}=0.48$ & - & 0.8348 \\
\hline $\mathrm{FSI}$ & 4.09 & 4.14 & 4.23 & 3.96 & $\bar{y}=4.10$ & - & 0.6937 \\
\hline ESI & 2.28 & 2.35 & 2.44 & 2.36 & $\bar{y}=2.36$ & - & 0.5232 \\
\hline FLI & 3.14 & 3.35 & 3.59 & 3.69 & $\bar{y}=2.71696+0.01438 W B W$ & 0.30 & 0.0011 \\
\hline ELI & 1.17 & 1.13 & 1.20 & 1.23 & $\bar{y}=1.18$ & - & 0.3220 \\
\hline
\end{tabular}

${ }^{1}$ Frum: full rumen; ERum: empty rumen; FRet: full reticulum; ERet: empty reticulum; FOma: full omasum; EOma: empty omasum; FAbo: full abomasum; EAbo: empty abomasum; FSI: full small intestine; ESI: empty small intestine; FLI: full large intestine; ELI: empty large intestine. 


\section{Conclusions}

The inclusion of wet brewery waste at the level of $31 \%$ as the roughage source in the diet of feedlot-finished lambs provides better carcass traits. Increasing levels of wet brewery waste in the diet increase the proportion of gastrointestinal content in lambs at the time of slaughter.

\section{References}

Brochier, M. A., \& Carvalho, S. (2009). Efeito de diferentes proporções de resíduo úmido de cervejaria sobre as características da carcaça de cordeiros terminados em confinamento. Arquivo Brasileiro de Medicina Veterinária e Zootecnia, 61(1), 190-195. doi: 10.1590/S0102-09352009 000100027

Carvalho, S., Frasson, M. F., Simões, F. S. B., Bernardes, G. M. C., Simões, R. R., Griebler, L., \& Mello, V. L. (2017). Resíduo úmido de cervejaria na terminação de cordeiros em confinamento e seus efeitos sobre as características da carcaça e dos componentes não carcaça. Arquivo Brasileiro de Medicina Veterinária e Zootecnia, 69(3), 742-750. doi: 10.1590/ 1678-4162-8573

Gois, G. C., Pessoa, R. M. dos S., Santos, R. N., Cunha, D. de S., Araújo, C. de A., \& Macedo, A. (2019). Características de carcaça e componentes não-carcaça de ovinos: uma revisão. Arquivos de Ciências Veterinárias e Zoologia, 22(4), 139-146. doi: 10.25110/arqvet.v22i4.2019

Hashimoto, J. H., Osório, J. C. da S., Osório, M. T. M., Bonacina, M. S., Lehmen, R. I., \& Pedroso, C. E. da S. (2012). Qualidade da carcaça, desenvolvimento regional e tecidual de cordeiros terminados em três sistemas. Revista Brasileira de Zootecnia, 41(2), 438-448. doi: 10.1590/S1516-3598 2012000200029 .

Instituto Brasileiro de Geográfia e Estatística (2018). Produção pecuária municipal. Decision Support Systems, 44(4), 1-51.

Lima, L. D. de, Rêgo, F. C. de A., Koetz, C., Jr., Ribeiro, E. L. de A., Constantino, C., Belan, L.,... Zundt, M. (2013). Interferência da dieta de alto grão sobre as características da carcaça e carne de cordeiros Texel. Semina: Ciências Agrárias, 34(6, Supl. 2), 4053-4064. doi: 1433/1679-0359.2013v34n6Supl2p4053

Moreno, G. M. B., Sobrinho, A. G. da S., Leão, A. G., Perez, H. L., Loureiro, C. M. B., \& Pereira, G. T. (2011). Rendimento dos componentes não-carcaça de cordeiros alimentados com silagem de milho ou cana-de-açúcar e dois níveis de concentrado. Revista Brasileira de Zootecnia, 40(12), 28782885. doi: 10.1590/S1516-35982011001 200035

National Research Council (2007). Nutrient requirements of small ruminants: sheep, goats, cervids, and new worlds camelids. Washington: National Academic Press.

Osório, J. C. da S., Osório, M. T. M., Fernandes, R. M., \& Vargas, F. M., Jr. (2014). Produção e qualidade de carne ovina. In B. S. Arturo, S. Bernardo-Villarroel, \& O. J. C. da Silveira (Eds.), Produção de ovinos no Brasil (pp. 399-445). São Paulo: Roca.

Osório, J. C. da S., Osório, M. T. M., Jardim, P. O. da C., \& Pimentel, M. A. (1998). Métodos para avaliação da produção de carne ovina, in vivo, na carcaça e na carne. Pelotas: UFPEL. 
Osório, J. C. da S., Osório, M. T. M., \& Sañudo, C. (2009). Características sensoriais da carne ovina. Revista Brasileira de Zootecnia, 38(Supl. Especial), 292-300. doi: 10.1590/ S1516-35982010000700028

Pellegrin, A. C. R. S., Pires, C. C., Mello, R. O., Müller, L., Carvalho, S., \& Lopes, J. F. (2013). Glicerina bruta no suplemento e seus efeitos nas características da carcaça e nos componentes do peso vivo de cordeiros lactentes. Arquivo Brasileiro de Medicina Veterinária e Zootecnia, 65(5), 1509-1518. doi: 10.1590/S1516-35982 009001300029
Silva, V. B., Fonseca, C. E. M. da, Morenz, M. J. F., Peixoto, E. L. T., Moura, E. dos S., \& Carvalho, I. das N. O. de. (2010). Resíduo úmido de cervejaria na alimentação de cabras. Revista Brasileira de Zootecnia, 39(7), 1595-1599. doi: 10.1590/S1516-35 982010000700028

Statistical Analysis System Institute (2016). $S A S^{\circledR}$ Studio 3.6: task reference guide. Cary, NC: SAS Institute Inc.

Valadares, S. C. F. Paulino, P. V. R., \& Magalhães, K. A. (2006). EXIGências nutricionais de zebuínos e tabelas de composição de alimentos - BR CORTE. Viçosa, MG: Suprema Gráfica Ltda. 